\section{JURNAL ABDIMAS

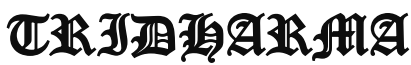 AtA}

\title{
PELATIHAN PEMBUDIDAYAAN IKAN DAN TANAMAN SEBAGAI KONSUMSI RUMAH TANGGA DAN PENINGKATAN EKONOMI KELUARGA
}

\author{
Rita Satria,Khayatun Nufus,Reni Hindriari, Nofiar, Priyono \\ Dosen Dan Mahasiswa prodi manajemen fakultas ekonomi \\ Universitas pamulang
}

\begin{abstract}
Email : dosen01679@unpam.ac.id ,nufus@uinjkt.ac.id, dosen00227@unpam.ac.id,, dosen01737@unpam.ac.id, dosen01738@unpam.ac.id
\end{abstract}

\begin{abstract}
ABSTRAK
Tujuan dari kegiatan Pengabdian Kepada Masyarakat ini adalah untuk melaksanakan salah satu Tri Dharma Perguruan Tinggi. Selain itu, melalui kegiatan Pengabdian Kepada Masyarakat ini, keberadaan perguruan tinggi diharapkan dapat memberikan pembekalan Pembudidayaan Ikan dan Tanaman, pemahaman dan pengenalan tentang Budikdamper untuk ikan dan tanaman kangkong, pembinaan cara untuk budidaya pemenuhan konsumsi keluarga melalui budidamber, penjelasan cara untuk budidaya pemenuhan konsusi keluarga melalui budidamber

Metode kegiatan yang digunakan adalah tim pelaksana mengunjungi yang beralamat di sekitar lokasi Masjid Qubatul Islam terletak di jalan Lele Kelurahan Bambu Apus , Kecamatan Pamulang Tangerang Selatan, dan memberikan pelatihan pada Hari juma dan sabtu t $13-14$ November 2020 . Pelatihan ini bertujuan agar budidaya pemenuhan konsusi keluarga melalui budidamber

Hasil yang diperoleh dari penelitian ini Solusi yang ditawarkan pada pelaksanaan pengabdian kepada masyarakat kali ini adalah solusi yang berbeda dari sebelumnya. Mungkin dulu pemerintah dengan berbagai program untuk membantu masyarakat lapisan menengah ke bawah salah satunya adalah melalui penyaluran program Unit Mikro, Kecil dan Menengah yang menyediakan produk-produk hasil karya masyarakat itu sendiri.
\end{abstract}

\section{Kata kunci : Pelatihan budidaya ikan dan tanaman sebagai konsumsi rumah tangga}

\section{ABSTRACT}

The purpose of this Community Service activity is to implement one of the Tri Dharma of Higher Education. In addition, through this Community Service activity, the existence of universities is expected to be able to provide briefing on Fish and Plant Cultivation, understanding and introduction to Budikdamper for fish and kangkong plants, fostering ways to cultivate family consumption fulfillment through cultivation, explaining ways to fulfill family consumption cultivation. through budidamber

The activity method used was the implementing team visited the location around the Qbatul Islam Mosque located on Jalan Lele, Bambu Apus Village, Pamulang District, South Tangerang, and provided training on Friday and Saturday 13-14 November 2020. This training aims to cultivate the fulfillment of family consumption through budidamber 


\section{JURNAL ABDIMAS

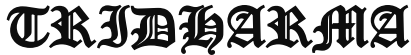

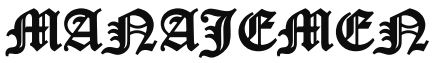

P-ISSN 2615-6849, E-ISSN 2716-070X

Jurnal ABDIMAS Vol.3,No.1,Desember 2021,Hal(57-71)

@Prodi Manajemen Fakultas Ekonomi Universitas Pamulang

Email: abdimasjurnal.unpam@ gmail.com Telp: (021) 741-2566

The results obtained from this research The solution offered in the implementation of community service this time is a different solution from the previous one. Perhaps in the past, the government had various programs to help the lower middle class society, one of which was through the distribution of the Micro, Small and Medium Unit program which provided products made by the community itself.

\section{Key words : Fish and plant cultivation training for household consumption}

\section{PENDAHULUAN}

Pandemi Covid-19 tidak hanya mengakibatkan keterpurukan ekonomi, tapi juga membuat masyarakat jadi lebih kreatif. Semangat untuk bangkit menghasilkan beragam kreativitas yang memiliki nilai ekonomi.

Salah satunya dilakukan budidaya kangkung dan lele. dan banyak upaya budidaya ini berhasil dengan pembuktian hasil budidaya tumbuh besar begitupun dengan kangkung tumbuh subur. Upaya budidaya ini dilakukan bukan saja oleh masyarakat umum tapi juga oleh kalangan mahasiswa sebagai bagian dari kegiatan wirausaha. Budidaya lele dengan kangkung dalam ember dapat dilakukan oleh siapapun. Tidak perlu membutuhkan pekarangan yang luas, tapi bisa memberikan nilai ekonomis.

Solusi ini dilakukan mengingat keterbatasan lahan untuk budidaya ikan dan mulai berkurangnya kualitas dan kuantitas air terutama di daerah perkotaan, sehingga budikdamper menjadi salah satu pilihan yang bisa diterapkan untuk mengatasi solusi pangan masa depan.

Budidaya ikan dalam ember dengan sistem aquaponik berpeluang meningkatkan kebutuhan akan protein hewani dan sayuran serta memudahkan masyarakat mendapatkan ikan dan sayur di lingkungan tempat tinggal. Cara ini sangat baik dikembangkan di panti asuhan dan tempattempat pengungsian karena bencana atau daerah perkotaan yang sempit lahan tinggal. Selain mudah dilakukan, budikdamper menggunakan media yang kecil, portabel, hemat air dan tidak membutuhkan listrik.
Terbukti dari hasil pengembangan yang dilakukan oleh Bapak Juli Nursandi dari Lampung telah membantu banyak masyarakat Indonesia untuk mencoba mengembangkan sistem aquaponik dengan memelihara ikan dan menanam sayur dalam ember.

\section{RUMUSAN MASALAH}

Berdasarkan paparan di atas, sebagai dasar pengembangan Pengabdian Kepada Masyarakat dapat dirumuskan sebagai berikut :

a. Bagaimana cara Pembudidayaan Ikan dan Tanaman?

b. Apa yang disebut dengan Budikdamper untuk ikan dan tanaman kangkung?

c. Bagaimana cara untuk budidaya pemenuhan konsumsi keluarga melalui budikdamber?

d. Bagaimana upaya Budikdamper dan budaya kangkung mampu meningkatkan ekonomi masyarakat?

\section{TUJUAN KEGIATAN}

a. Untuk memberi pembekalan Pembudidayaan Ikan dan Tanaman

b. Untuk memberi pemahaman dan pengenalan tentang Budikdamper untuk ikan dan tanaman kangkung

c. Untuk memberi pembinaan cara untuk budidaya pemenuhan konsumsi keluarga melalui budikdamber.

d. Untuk menberi penjelasan cara untuk budidaya pemenuhan 


\section{JURNAL ABDIMAS

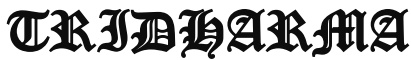

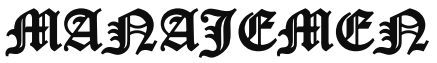

P-ISSN 2615-6849, E-ISSN 2716-070X

Jurnal ABDIMAS Vol.3,No.1,Desember 2021,Hal(57-71)

@Prodi Manajemen Fakultas Ekonomi Universitas Pamulang

Email: abdimasjurnal.unpam@gmail.com Telp: (021) 741-2566 konsumsi keluarga melalui budikdamber

\section{TINJAUAN PUSTAKA}

Peraturan Presiden (Perpres) Nomor 13 Tahun 2015 tentang Kemenristekdikti Pasal 2 menyebutkan bahwa Kemenristekdiki memiliki tugas menyelenggarakan urusan pemerintah di bidang riset, teknologi dan pendidikan tingga untuk membantu Presiden dalam menyelenggarakan pemerintahan Negara. Sebagai tindak lanjut atas Perpres tersebut, maka Kemenristekdikti melalui visi dan misinya yang tercantum dalam Permenristekdikti No 50 Tahun 2017 tentang Rencana Strategis (Renstra) Kemenristekdikti, berusaha untuk mewujudkan perguruan tinggi yang bermutu. Perguruan tinggi yang bermutu ialah yang menghasilkan lulusan yang berpengetahuan, terdidik dan terampil serta memiliki kemampuan iptek dan inovasi guna meningkatkan daya saing bangsa.

Peningkatan daya saing bangsa dapat terwujud apabila iptek dan pendidikan tinggi dapat memberikan kontribusi dalam penguatan perekonomian dan peningkatan kesejahteraan masyarakat yang ditunjukan melalui keunggulan produk teknologi hasil litbang yang dihasilkan oleh industry/perusahaan yang didukung oleh lembaga litbang seperti Lembaga Pemerintah Non Kementerian (LPNK), Lembaga Pemerintah Kementerian (LPK), Badan Usaha dan Perguruan Tinggi.

Renstra Kemenristekdikti juga menjelaskan bahwa perguruan tinggi dapat berperan sebagai agen pengembangan ekonomi. Hal tersebut juga disampaikan oleh Menristekdikti, Prof. Mohamad Nasir saat menjadi Pembina Upacara Hari Pendidikan Nasional (Hardiknas) di Lapangan Upacara Telkom University. Beliau mengatakan, "saatnya perguruan tinggi berperan sebagai agent of economic development disamping agent of education dan agent of research and development, dalam melaksanakan Tridharma memperhatikan dampak dari aktivitas nya terhadap pengembangan ekonomi", (2017). Sehingga untuk memenuhi harapan masyarakat, perguruan tinggi dituntut untuk dapat mengahasilkan inovasi yang dapat memberikan manfaat ekonomi bagi masyarakat secara luas. Agar hal tersebut dapat tercapai dengan baik, pelaksanaan penelitian dan PKM di perguruan termasuk pemberdayaan masyarakat harus diarahkan untuk mencapai tujuan dan standar tertentu. Oleh karena itu, peran perguruan tinggi sangatlah penting dalam melakukan PKM, termasuk melakukan kegiatan pemberdayaan masyarakat. Kita dapat melihat keterkaitan perguruan tinggi dalam meningkatkat kesejahteraan masyarakat melalui gambar di halaman berikutnya.

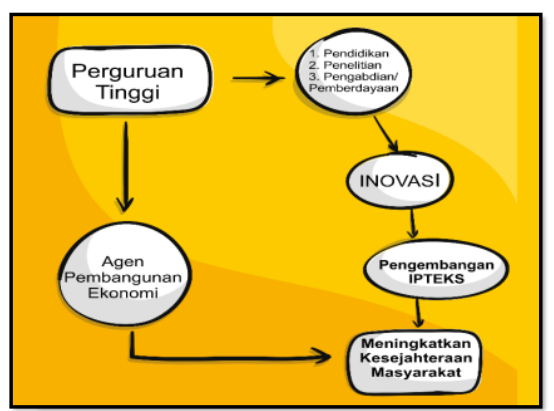

Gambar 2.1. Peran Perguruan Tinggi

Pengelolaan pengabdian kepada masyarakat pada perguruan tinggi diarahkan untuk mencapai hal-hal sebagai berikut:

1. Mewujudkan keunggulan pada pengabdian kepada masyarakat di perguruan tinggi;

2. Meningkatkan daya saing perguruan tinggi di bidang pengabdian kepada masyarakat pada tingkat nasional dan internasional;

3. Meningkatkan angka artisipasi dosen dalam melakukan pengabdian kepada masyarakat;

4. Meningkatkan kapasitas pengelolaan pengabdian kepada masyarakat di 


\section{JURNAL ABDIMAS

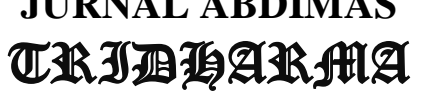

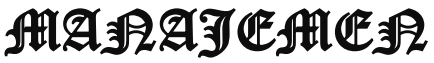

perguruan tinggi

5. Memfungsikan potensi perguruan tinggi dalam meningkatkan daya saing.

\section{STRATEGI PEMBERDAYAAN MASYARAKAT DI PERGURUAN TINGGI}

Kegiatan pemberdayaan masyarakat juga memerlukan strategi khusus agar kegiatan pemberdayaan tersebut dapat mencapai tujuan yang telah ditetapkan. Strategi tersebut meliputi pendekatan, komunikas, pendampingan dan lain sebagainya. Anda dapat melihat strategi-strategi yang dapat digunakan dalam kegiatan pemberdayaan masyarakat melalui ilustrasi berikut.

\section{GAMBAR 2.1 : StRATEGI KegiatAN PEMBERDAYAAN MASYARAKAT}

\section{a. Metode Pendekatan yang Sesuai}

Pendekatan yang baik diperlukan dalam melakukan pemberdayaan masyarakat. Setiap masyarakat tentu memiliki karakteristik dan kebutuhan yang berbeda-beda. Sehingga pendekatan yang digunakan juga harus sesuai dengan masyarakat tersebut. Menurut United Nations Development Programs (2016), terdapat beberapa pendekatan yang dapat digunakan dalam melakukan kegiatan pemberdayaan masyarakat antara lain:

\section{1) Collaborative}

Pendekatan kolaboratif
mengacu pada hubungan
antara pemberi kegiatan
dengan masyarakat yang
akan diberdayakan. Kegiatan
pemberdayaan ran harus
mendengar dan

merespon ide-ide yang diberikan oleh masyarakat tentang apa yang akan dilakukan dan bagaimana
melakukannya.

2) Participatory

Pendekatan partisipatif mengajak masyarakat untuk ikut serta dalam melakukan kegiatan pemberdayaan masyarakat. Pendekatan ini menghormati dan secara aktif meningkatkan pengetahuan, keterampilan dan kekuatan yang ada pada masyarakat sekitar.

3) Inclusive

Pendekatan inklusif melibatkan masyarakat dalam seluruh proses kegiatan pemberdayaan masyarakat. Pendekatan ini menganggap bahwa masyarakat setara dengan mitra atau rekan kerja, sehingga harus dilibatkan mulai dari perencanaan, pelaksanaan hingga evaluasi.

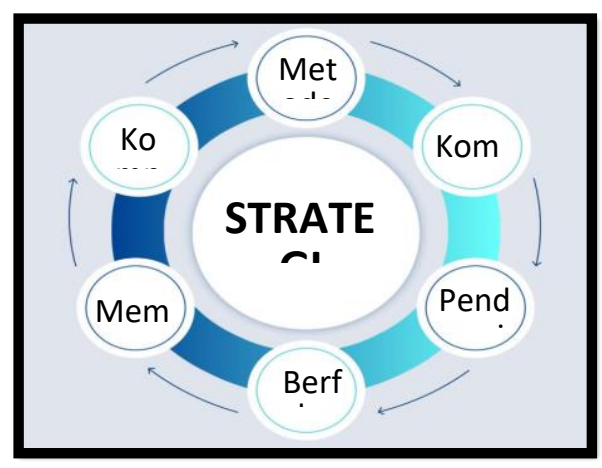

4) Quality Assurance-Oriented

Pendekatan ini fokus untuk memberikan pengawasan pada kualitas, keamanan, aksesibilias dan tingkat penerimaan pelayanan dan program, kesepakatan masyarakat, kepaduan dan keterkaitan masyarakat dengan memberikan pelayanan sepenuhnya.

5) Bottom-Up

Pendekatan ini berfokus untuk membangun hubungan dari bawah keatas, yakni mulai dari hubungan antar komunitas masyarakat, antar penerima kegiatan pemberdayaan dengan pemberi kegiatan pemberdayaan, antar institusi dan sistem yang ada diatasnya. 


\section{JURNAL ABDIMAS

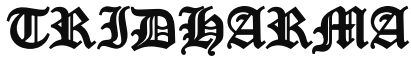

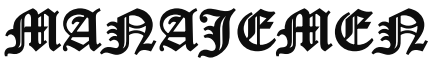

P-ISSN 2615-6849, E-ISSN 2716-070X

Jurnal ABDIMAS Vol.3,No.1,Desember 2021,Hal(57-71)

@Prodi Manajemen Fakultas Ekonomi Universitas Pamulang

Email: abdimasjurnal.unpam@ gmail.com Telp: (021) 741-2566

\section{b. KOMUNIKASI YANG BAIK}

Ketika dosen akan melakukan kegiatan pemberdayaan, tentunya harus membina hubungan yang baik dengan masyarakat di lingkungan yang dituju. Hubungan yang baik akan tercipta melalui komunikasi yang baik. Komunikasi sangat penting dalam pemanfaatan kegiatan pemberdayaan masyarakat, sebagaimana disebutkan dalam Knowsley (2011), "effective communication is a vital element in empowering". Metode yang digunakan dalam komuikasi juga harus inovatif. Saat ini komunikasi dapat dilakukan melalui berbagai media, termasuk media sosial. Namun, metode yang digunakan juga harus disesuaikan dengan keadaan dan karakteristik masyarakat tersebut. Penggunakaan metode yang tepat akan berdampak baik pada kegiatan pemberdayaan yang akan dilakukan.

\section{c. PENDAMPIngan BERKELANJUTAN}

Pendampingan yang dilakukan pada masyarakat harus secara berkelanjutan. Hal ini ini bukan berarti menjadikan masyarakat tersebut menjadi tidak mandiri, melainkan memastikan bahwa kegiatan pemberdayaan tetap berjalan sesuai tujuan. Jika melihat dari esensi pemberyaan, kita mengetahui bahwa kegiatan pemberdayaan dapat dikatakan berhasil apabila masyarakat dapat benarbenar mandiri dalam meningkatkan kualitas hidupnya, tidak hanya pada saat kegiatan pemberdayaan tersebut dilakukan saja, namun dalam jangka panjang setelah kegiatan pemberdayaan tersebut berlangsung. Maka dari itu, pendampingan harus terus menerus dilakukan dengan periode tertentu agar masyarakat dapat memberdayaakan dirinya secara mandiri dalam jangka panjang.

\section{d. BERFOKUS PADA MASYARAKAT}

Kegiatan pemberdayaan masyarakat bertujuan untuk menjadikan masyarakat lebih berdaya dan mandiri dalam meningkatkan kualitas dan kesejahteraan hidupnya, sebagaimana dinyatakan dalam Tannahill (2016), "Empowerment activity focuses on people, as well as place, and provides invesments in each. Community empowerment initiatives need to include an educational imperative that focuses on developing skills and confidence in the people who comprises communities". Agar tujuan tersebut dapat tercapai, kegiatan pemberdayaan harus berfokus pada masyarakat itu sendiri. Agen pemberdayaan harus dapat menganalisis apa bagaimana karakteristik masyarakat tersebut, baik dari segi lingkungan maupun budayanya. Kemudian, agen pemberdayaan harus menganalisis apa yang dibutuhkan atau menjadi permasalahan bagi masyarakat. Setelah itu, agen pemberdayaan harus bersamasama dengan masyarakat mencari cara yang sesuai sebagai alternatif pemecahan masalah tersebut.

\section{e. Membangun Networking}

Kemajuan teknologi informasi menjadi modal dalam memperluas networking. Hal ini juga harus dapat dimanfaatkan oleh masyarakat. Agen pemberdayaan, harus dapat mengarahkan masyarakat untuk dapat melakukan networking. Networking akan sangat berguna bagi masyarakat dalam melakukan sharing knowledge, memasarkan produk ataupun kebudayaan mereka, sebagai sarana dalam mendapatkan informasi serta melakukan inovasi-inovasi yang lebih baik nantinya. Apa yang telah dilakukan selama proses kegiatan pemberdayaan, perlu terus-menerus dikembangkan, sehingga membangun networking dapat menjadi salah satu strategi yang dapat dilakukan oleh agen pemberdayaan bersama dengan masyarakat.

\section{f.KOMPETENSI AGEN PEMBERDAYAAN}

Pemberdayaan masyarakat ini adalah proses membangun manusianya dengan meningkatkan harkat dan martabat serta memberikan 


\section{JURNAL ABDIMAS

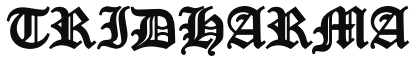

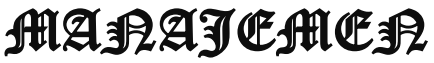

P-ISSN 2615-6849, E-ISSN 2716-070X

Jurnal ABDIMAS Vol.3,No.1,Desember 2021,Hal(57-71)

@Prodi Manajemen Fakultas Ekonomi Universitas Pamulang

Email: abdimasjurnal.unpam@gmail.com Telp: (021) 741-2566 kesejahteraan bagi masyarakat. Oleh karena itu sebagai agen pemberdaya seorang dosen perlu memiliki kompetensi yang bisa mendorong masyarakat untuk mau dan mampu berubah ke arah yang lebih baik sesuai dengan potensi dan kebutuhan masyarakat.

\subsection{Pelatihan}

\section{Arti Pelatihan}

Pelatihan merujuk kepada cara untuk memperoleh pengetahuan dan keahlian-keahlian sebagai sebuah hasil dari pembelajaran mengenai kejuruan atau keahlian-keahlian praktis dan pengetahuan yang berhubungan kepada kompetensikompetensi spesifik yang berguna. Pelatihan adalah sebuah konsep manajemen sumber daya manusia yang sempit yang melibatkan aktivitas-aktivitas pemberian instruksi-instruksi khusus yang direncanakan (seperti misalnya pelatihan terhadap prosedur-prosedur operasi pelatihan yang spesifik) atau pelatihan keahlian (seperti misalnya pelatihan yang berhubungan dengan tugas, programprogram pengenalan pekerjaan). Chris Rowley, Manajemen Sumber Daya Manusia, Jakarta: Rajawali Pers, 2012, hal. 436

Pelatihan adalah suatu proses pendidikan jangka pendek dengan menggunakan prosedur-prosedur yang sistimatis dan terorganisir,sehingga seseorang mau belajar mengenai pengetahuan teknik dan keahlian untuk tujuan tertentu ( Hasibuan 2008:69).

Pelatihan adalah setiap usaha untuk memperbaiki performansi pekerja pada suatu pekerjaan tertentu yang sedang menjadi tanggungjawabnya. Menurutnya istilah pelatihan sering disamakan dengan istilah pengembangan, perbedaannya kalau pelatihan langsung terkait dengan performansi kerja pada pekerjaan yang sekarang, sedangkan pengembangan tidaklah harus, pengembangan mempunyai scoupe yang lebih luas dibandingkan dengan pelatihan. (Gomes:2003:197).Pelatihan
Iebih terarah pada peningkatan kemampuan dan keahlian SDM organisasi yang berkaitan dengan tanggung jawab individu yang bersangkutan saat ini ( current job oriented). Sasaran yang ingin dicapai dan suatu program pelatihan adalah peningkatan kinerja individu dalam jabatan atau fungsi saat ini. Pengembangan cenderung lebih bersifat formal, menyangkut antisipasi kemampuan dan keahhan individu yang harus dipersiapkan bagi kepentingan jabatan yang akan datang. Sasaran dan program pengembangan menyangkut aspek yang lebih luas yaitu peningkatan kemampuan individu untuk mengantisipai perubahan yang mungkin terrjadi tanpa direncanakan(unplened change) atau perubahan yang direncanakan (planed change). (Syafaruddin:2001:2 17).

\section{1) Pengertian \\ Pengembangan (Development)}

Konsep Pengembangan Sumber Daya Manusia (PSDM) dalam organisasi, hakikatnya merupakan suatu usaha demi peningkatan daya saing terhadap ancaman lingkungan eksternal dan upaya meningkatkan daya inovatif demi menciptkan peluang. Pengembangan Sumber Daya Manusia dalam organisasi bersifat integral sebagai individu dan sistem serta organisasi sebagai wadah SDM secara terencana dan berkesinambungan untuk menigkatkan kompetensi masyarakat melalui program pelatihan, pendidikan, dan pengembangan (Noe, 2008). Secara umum Pengembangan (development) dapat diartikan sebagai penyiapan individu untuk memikul tanggung jawab yang berbeda atau yang lebih tinggi dalam perusahaan, organisasi, lembaga atau instansi pendidikan.

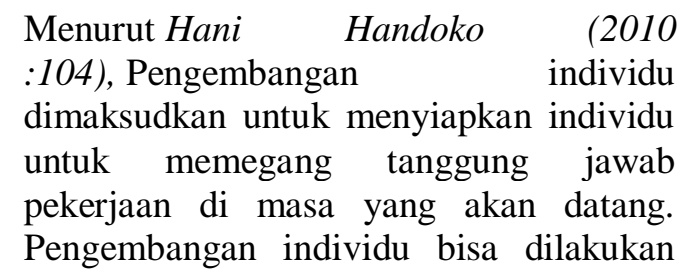




\section{JURNAL ABDIMAS

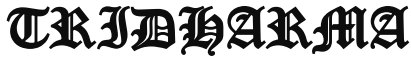

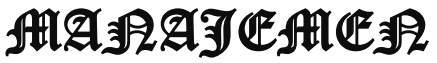

P-ISSN 2615-6849, E-ISSN 2716-070X

Jurnal ABDIMAS Vol.3,No.1,Desember 2021,Hal(57-71)

@ Prodi Manajemen Fakultas Ekonomi Universitas Pamulang

Email: abdimasjurnal.unpam@ gmail.com Telp: (021) 741-2566 secara formal maupun informal. Secara formal berarti individu ditugaskan oleh perusahaan.Sedangkan secara informal berarti individu melatih dan mengembangkan dirinya ataskeinginan dan inisiatif sendiri tanpa ditugaskan oleh perusahaan. Program pengembangan individu akan membuat individu semakin produktif sehingga memungkinkan organisasi atau perusahaan mempertimbangkan untuk melakukan pengembangan individu.

Masyarakat yang akan mengikuti program pengembangan adalah masyarakat individu supaya lebih memahami, terampil, dan ahli dalam menyelesaikan pekerjaannya, supaya mereka lebih memahami technical skill,human skill, conceptual skill, dan managerial skill (Simamora 2008 : 268).

\section{Tujuan Pelatihan dan Pengembangan $S D M$}

Menurut Pasal 9 Undang-undang Ketenaga kerjaan Tahun 2003, pelatihan kerja diselenggarakan dan diarahkan untuk membekali, meningkatkan dan mengembangkan kompetensi kerja guna meningkatkan kemampuan, produktivitas, dan kesejahteraan. Tujuan pelatihan dan pengembangan SDM pada dasarnya dikelompokan ke dalam lima bidang : 1 . Memperbaiki kinerja, 2. Memutakhirkan keahlian individu sejalan dengan kemajuan teknologi, 3. Mengurangi waktu pembelajaran bagi individu agar agar kompeten dalam pekerjaan, 4. membantu memecahkan masalah operasional, 5 . Mempersiapkan individu yang lebih maju.

\section{Arti BUDIKDAMBER}

Pengertian budidaya adalah suatu usaha yang tersusun secara terencana Untuk memelihara dan mengembangbiakan suatu tanaman atau hewan. Budidaya memiliki tujuan agar tetap lestari dan bisa memperoleh hasil yang bermanfaat dan berguna untuk memenuhi kebutuhan hidup manusia.
Beberapa jenis sumber daya hayati yang sering dibudidayakan yaitu produk tanaman seperti tanaman pangan, tanaman hias, aneka jenis sayuran, ayam, sapi, dan ikan. Dari kegiatan budidaya tersebut diharapkan bisa menghasilkan produk yang dapat memenuhi kebutuhan manusia sehari-hari serta menghasilkan keuntungan bagi pembudidaya.

\section{Latar belakang Budikdamber}

Saat ini Indonesia tengah diuji dengan adanya pandemi virus Covid 19. Berbagai cara dilakukan untuk menekan penyebaran virus ini, mulai dari pembelajaran daring kepada seluruh civitas akademika, pemberlakuan sistem local lockdown, penutupan berbagai sarana umum, dan kebijakankebijakan lain yang menganjurkan seluruh masyarakat dari berbagai kalangan untuk tetap dirumahaja.

Ada banyak hal yang dapat Anda lakukan agar tetap produktif selama \#dirumahaja. BUDIKDAMBER atau dikenal sebagai Budidaya Ikan Dalam Ember merupakan salah satu solusi yang bisa Anda lakukan selama dirumahaja. BUDIKDAMBER menggunakan media yang kecil, hemat air, portabel, dan tidak membutuhkan listrik. Anda bisa menebar 40-60 benih ikan dalam ember yang berisi 80 liter air. BUDIKDAMBER juga dapat menjadi solusi dari semakin berkurangnya lahan pertanian yang ada karena perkembangan pembangunan yang pesat. Dengan semakin maraknya pembangunan pemukiman dan perekonomian di wilayah perkotaan, semakin meningkat pula alih fungsi lahan yang terjadi.

Dengan semakin menyempitnya potensi lahan di wilayah perkotaan yang bisa dimanfaatkan, maka pemanfaatan pekarangan merupakan salah satu opsi yang bisa dipilih. Di masa pandemi seperti sekarang ini, pemanfaatan pekarangan sangat erat kaitannya dengan usaha mencapai ketahanan pangan masyarakat yang dimulai dari skala rumah tangga. 


\section{JURNAL ABDIMAS

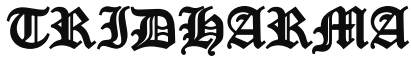

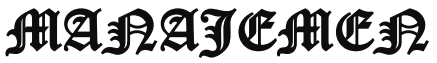

P-ISSN 2615-6849, E-ISSN 2716-070X

Jurnal ABDIMAS Vol.3,No.1,Desember 2021,Hal(57-71)

@ Prodi Manajemen Fakultas Ekonomi Universitas Pamulang

Email: abdimasjurnal.unpam@ gmail.com Telp: (021) 741-2566
Ada beberapa jenis ikan yang dapat didederkan atau dibesarkan dengan mudah dalam BUDIKDAMBER, diantaranya ikan lele, ikan mujair, dan ikan nila. Sistem BUDIKDAMBER dapat dilakukan bersamaan dengan tanaman akuaponik seperti kangkung, bayam, dan sawi. Ikan lele dan sayur kangkung menjadi bahan yang paling umum digunakan pada metode BUDIKDAMBER ini.

\section{Sekilas Tentang BUDIKDAMBER}

Budidaya ikan yang dibarengi dengan kegiatan hidroponik ini merupakan hasil temuan Dosen Politeknik Negeri Lampung, Juli Nursandi, S.Pi, M.Pi. Lewat metode ini Anda bisa mewujudkan dua hobi sekaligus dalam satu wadah, yakni budidaya ikan dan bercocok tanam, serta tidak terkendala dengan lahan yang sempit. Metode ini diklaim ideal diterapkan di kota yang notabene lahannya rata-rata terbilang minim.

Seiring berjalannya waktu, perwujudan BUDIKDAMBER diawali dari kegiatan penyuluhan perikanan pada sekelompok ibu rumah tangga yang tergabung dalam keanggotaan PKK. untuk menumbuhkan semangat kewirausahaan ibu-ibu rumah tangga dan warga secara umum, maka perlu dilakukan pendampingan. Salah satunya dengan mengenalkan pengembangan budidaya ikan sistem BUDIKDAMBER.

BUDIKDAMBER mengadaptasi teknik Yumina-Bumina yang merupakan teknik budidaya yang memadukan antara ikan dan sayuran serta buah-buahan. Berdasar beberapa penelitian, pada budidaya Yumina-Bumina dikenal empat sistem, yaitu; rakit, aliran atas, aliran bawah serta pasang surut.

Pada sistem aliran atas, distribusi air dilakukan lewat atas ke setiap wadah media tanam sehingga nutrisi yang berasal dari limbah budidaya dapat tersebar merata ke setiap batang tanaman. Untuk membuat sistem aliran atas diperlukan bahan seperti bak ikan, wadah media tanam, saluran air, pompa air, arang, ikan, dan sayuran.
2)

\section{Aplikasi BUDIKDAMBER}

Bahan yang dibutuhkan dalam budidaya berupa ember 80 liter, gelas plastik, kawat, arang, benih ikan lele, dan sayuran kangkung. Tahap selanjutnya air diendapkan dalam ember selama satu hari. Kemudikan membuat media tanam sayuran berupa gelas plastik (sebagai pot) yang dilubangi kawat sebagai tempat untuk digantungkan ke mulut ember.

Selanjutnya, arang dibersihkan sebagai pengganti tanah dan dimasukkan ke dalam pot plastik. Terakhir tanaman kangkung dimasukkan ke dalam pot. Yang harus diperhatikan saat meletakkan pot harus sebagian terendam air. Ember air yang sudah diendapkan, sehari kemudian dimasukkan ikan lele,nila, atau patin. Dalam satu ember bisa diisi sekitar 40 ekor benih lele ukuran 7-9.

3)

\section{Masa Pemanenan}

Kegiatan budikdamber dilaksanakan kurang lebih 4 bulan. Hasil dari kegiatan tersebut adalah panen ikan lele dan sayur kangkung. Lele sudah bisa dipanen mulai 1,5-2 bulan dari masa pemeliharaan. Panen lele tidak dilakukan secara serentak untuk seluruh ember, karena besar ikan lele tidak seragam untuk pemeliharaan selama dua bulan tersebut.

Sementara panen kangkung pertama kali dilakukan pada masa pemeliharaan selama 2-3 minggu. Jumlah awal panen kangkung rata-rata 1 ikat per dua ember. Panen berikutnya sekitar satu hingga dua minggu dengan jumlah panen sekitar lebih banyak dari panen pertama yaitu satu ikat satu ember.

Jumlah panen kangkung akan semakin berkurang ketika memasuki bulan ketiga dan keempat pemeliharaan. Ketika jumlah panen kangkung sudah mulai berkurang bisa dilakukan penanaman kembali melalui pergantian kangkung dengan bibit yang baru. 


\section{JURNAL ABDIMAS

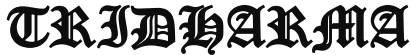

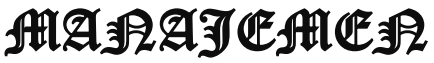

P-ISSN 2615-6849, E-ISSN 2716-070X

Jurnal ABDIMAS Vol.3,No.1,Desember 2021,Hal(57-71)

@ Prodi Manajemen Fakultas Ekonomi Universitas Pamulang

Email: abdimasjurnal.unpam@gmail.com Telp: (021) 741-2566
Penggunaan ember sebagai pengganti kolam adalah karena hemat tempat. Ketika tempat menjadi keterbatasan dalam memulai bisnis atau usaha sampingan, maka menggunakan ember dianggap solusi terbaik. Tidak seperti menggunakan kolam, memanen dari ember lebih mudah karena Anda tinggal membuang airnya saja.

\section{Solusi Ketahananan Pangan Disaat Pandemi Dengan BUDIKDAMBER}

Dasar dari teknik ini adalah sistem akuaponik, yaitu menanam tanaman dan memelihara ikan dalam satu wadah. Unsur hara yang berasal dari kotoran ikan akan dimanfaatkan oleh tanaman. Bagaikan simbiosis mutualisme, tanaman akan berfungsi sebagai filter vegetasi yang akan mengurai zat racun pada kotoran ikan menjadi zat yang tidak berbahaya bagi ikan. Tanaman juga akan menyuplai oksigen pada air yang digunakan untuk memelihara ikan. Secara umum, pengertian budidaya adalah suatu kegiatan terencana dalam memelihara sumber daya hayati pada suatu areal lahan untuk diambil manfaat/ hasil panennya.

\section{Budidaya Tanaman Sayur}

Budidaya tanaman sayur bertujuan untuk menghasilkan bahan pangan dengan memanfaatkan sumber daya tumbuhan yang ditanam. Biasanya hasil produksi dari budidaya tanaman sayur ini akan menghasilkan beberapa jenis tanaman yang dapat dikonsumsi. Beberapa diantaranya adalah:

a, sayur bayam

b. sayur kangkung

c. sayur seledri

d. kol

e. selada, dll
A. Budidaya perikanan adalah suatu kegiatan memelihara serta mengembangbiakkan jenis ikan tertentu untuk mendapatkan hasil yang lebih bermanfaat. Biasanya ada dua jenis ikan yang dibudidayakan, yaitu ikan hias dan ikan yang layak untuk dikonsumsi, diantaranya:

- Ikan lele

- Ikan mujaer

- Ikan mas

- Ikan nila

- $\quad$ Ikan gurame, dll

\subsection{Penguatan Ekonomi Keluarga}

Program Pemberdayaan Ekonomi

Keluarga bertujuan untuk menumbuhkan dan meningkatkan minat, semangat, ketrampilan serta kinerja keluarga dalam bidang usaha ekonomi produktif. Melalui upaya ini diharapkan keluarga-keluarga yang masih tergolong Pra Sejahtera dan sejahtera alasan ekonomi mampu berusaha dalam rangka meningkatkan ekonomi dan pendapatan keluarga. Kegiatan pokok pemberdayaan ekonomi keluarga yang dilakukan melalui kelompok kegiatan ekonomi produkti, dalam hal ini Kelompok UPPKS menekankan pada upaya-upaya yang berkaitan dengan pemberian fasilitas dan dapat meningkatkan akses pada berbagai sumber daya yang dibutuhkan keluarga agar dapat meningkatkan kualitas usahanya, antara lain dalam pengembangan modal produksi pemasaran dan peningkatan ketrampilan.

Program Pemberdayaan Ekonomi Keluarga ini menekankan pada aspek kualitas produksi, variasi produk serta jangkauan pemasaran. Melalui kelompok yang akan terbentuk ini diharapkan keluarga mampu meningkatkan akses yang ada dan tersedia.

\section{10. BUDIDAYA PERIKANAN}




\section{JURNAL ABDIMAS

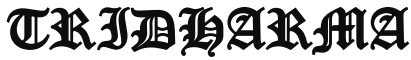

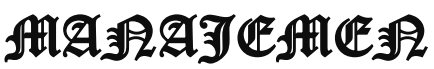

P-ISSN 2615-6849, E-ISSN 2716-070X

Jurnal ABDIMAS Vol.3,No.1,Desember 2021,Hal(57-71)

$@$ Prodi Manajemen Fakultas Ekonomi Universitas Pamulang

Email: abdimasjurnal.unpam@ gmail.com Telp: (021) 741-2566
Kita ketahui bersama bahwa dalam mengendalikan kuantitas penduduk dan meningkatkan kualitas penduduk, kita menerapkan konsep pembangunan berwawasan kependudukan dan pembangunan pemberdayaan keluarga. Dengan konsep pembangunan ini, penduduk dilihat secara utuh yaitu sebagai diri pribadi, sebagai anggota keluarga, sebagai anggota masyarakat, sebagai warga Negara dan sebagai himpunan kuantitas.

Sementara keluarga dipandang sebagai wahana strategis dalam pengembangan sumber daya manusia potensial yang melahirkan manusia-manusia pembangunan yang handal di segala bidang. Logikanya, keluarga sebagai unit terkecil dari masyarakat memiliki peran yang sangat penting dalam peningkatan kualitas SDM secara umum, mengingat keluarga merupakan lingkungan yang pertama dan utama bagi setiap individu.

Langkah-langkah strategis yang dapat dilakukan terkait dengan pemberdayaan ekonomi keluarga dalam rangka membangun keluarga yang mandiri dan sejahtera, adalah pertama, keluarga sasaran harus dikondisikan dalam suasana kondosif untuk mampu berusaha dari sisi mental dan spiritual. Artinya jiwa berwira usaha harus dibangun dan dimantapkan lebih dahulu, agar setiap anggota keluarga memiliki sikap mental yang memadai sebagai seorang wirausahaan yang mandiri. Untuk upaya yang pertama ini, pembinaan pada keluarga melalui KIE dan konseling yang efektif menjadi kunci keberhasilan untuk membawa keluarga-keluarga sasaran menjadi keluarga yang siap untuk memberdayakan diri dalam aspek ekonomi.

\section{METODE PELAKSANAAN}

Permasalahan yang muncul adalah karena :
a. Adanya pandemi COVIT- 19
b. Banyaknya masyarakat yang mengalami pemutusan hubungan kerja
c. Berkurangnya penghasilan masyarakat , bahkan terhentinya penghasilan keluarga.

d. Kelesuan ekonomi keluarga dalam masyarakat secara luas dan kelesuan ekonomi negara secara keseluruhan.

e. Kurangnya pembekalan ketrampilan yang dibutuhkan masyarakat unt7uk mengangkat ekonomi keluarganya.

Berikut adalah gambar kerangka

\begin{tabular}{|l|l|l|l|}
\hline No & Waktu & \multicolumn{1}{|c|}{ Acara } & $\begin{array}{l}\text { Pemateri/ } \\
\text { Penaggung } \\
\text { Jawab }\end{array}$ \\
\hline 1. & $\begin{array}{l}09.00- \\
10.00\end{array}$ & $\begin{array}{l}\text { Tata cara } \\
\text { ternak lele } \\
\text { dalam } \\
\text { ember dan } \\
\text { tanam } \\
\text { kangkung }\end{array}$ & $\begin{array}{l}\text { Rita } \\
\text { Satria, } \\
\text { S.E.,M.M }\end{array}$ \\
\hline 2. & $\begin{array}{l}10.00- \\
11.00 .\end{array}$ & $\begin{array}{l}\text { Tanya } \\
\text { Jawab }\end{array}$ & TIM PKM \\
\hline 3. & $\begin{array}{l}11.00- \\
11.30\end{array}$ & $\begin{array}{l}\text { Pemberian } \\
\text { Cindera } \\
\text { mata dan } \\
\text { Penutup }\end{array}$ & $\begin{array}{l}\text { MC dan } \\
\text { Panitia }\end{array}$ \\
\hline
\end{tabular}

kegiatan PKM ini :

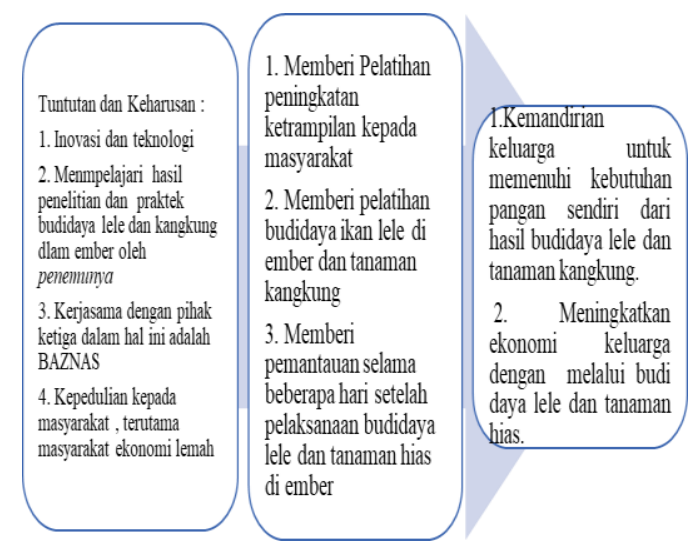

Gambar 3.1 Kerangka Pemecahan Masalah

\subsection{Realisasi Pemecahan Masalah}

a. Menetapkan tempat atau lokasi yang tepat untuk melakukan kegiatan PKM ini.

b. Memberikan pelatihan tentang ketrampilan masayarakat, terutama keluarga kurang mampu yang terdampak kelesuan ekonomi negara/masyarakat..

c. Memberikan modal berupa ember dengan bibit lele dan bibit tanaman 


\section{JURNAL ABDIMAS

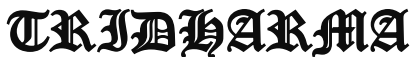

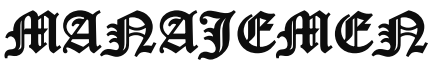

P-ISSN 2615-6849, E-ISSN 2716-070X

Jurnal ABDIMAS Vol.3,No.1,Desember 2021,Hal(57-71)

@Prodi Manajemen Fakultas Ekonomi Universitas Pamulang

Email: abdimasjurnal.unpam@ gmail.com Telp: (021) 741-2566 kangkung yang akan dibudidayakan.

d. Memantau perkembangan ternak lele dan tanaman kangkung yang sudah diberikan selama beberapa hari (sebulan ).

\subsection{Khalayak Sasaran}

Kegiatan pelatihan ini dilakukan di masayarakat sekitas Masjid Qubatul Islam dengan sasaran yang sangat terdampak kondisi kelesuan ekonomi saat ini. Mereka dipilih melalui prosedur seleksi setiap RT yang berada di lingkungan Masjid tersebut. Sasaran ditebtukan dengan berdasarkan berbagai pertimbangan, dengan tetap mengikuti ketentuan yang diharuskan oleh Badan Amil Zakat dan Infak Nasional.

\subsection{Tempat dan Waktu}

Kegiatan Pengabdian Kepada Masyarakat yang kali ini memilih masyarakat yang bertempat tinggal di sekitar lokasi Masjid Qubatul Islam terletak di jalan Lele Kelurahan Bambu

Apus , Kecamatan Pamulang Tangerang Selatan, Banten. Pelatihan diadakan selam 2 hari, yaitu kamis dan jumat, tanggal 13 sampai 14 November 2020.

Hari Jumat, 13 November 2020

Tabel 4.1 Rundown Acara Pelatihan hari pertama

\begin{tabular}{|c|c|c|c|}
\hline No & Waktu & Acara & $\begin{array}{l}\text { Pemateri/ } \\
\text { Penaggung } \\
\text { Jawab }\end{array}$ \\
\hline 1. & $\begin{array}{l}07.00- \\
08.00\end{array}$ & $\begin{array}{l}\text { Ramah } \\
\text { Tamah dan } \\
\text { Sarapan Pagi }\end{array}$ & Panitia \\
\hline 2. & $\begin{array}{l}08.00- \\
09.00\end{array}$ & $\begin{array}{l}\text { Pembukaan } \\
\text { Acara }\end{array}$ & $\mathrm{MC}$ \\
\hline 3. & $\begin{array}{l}09.00- \\
09.15\end{array}$ & $\begin{array}{l}\text { Sambutan } \\
\text { Tim PKM }\end{array}$ & $\begin{array}{l}\text { Ketua } \\
\text { PKM }\end{array}$ \\
\hline 4. & $\begin{array}{l}09.15- \\
09.45\end{array}$ & $\begin{array}{l}\text { Sambutan } \\
\text { Ketua DKM } \\
\text { Masjid } \\
\text { Qubatul } \\
\text { Islaml } \\
\end{array}$ & $\begin{array}{l}\text { Bp. } \\
\text { Ubaidillah } \\
\text {, S.E }\end{array}$ \\
\hline
\end{tabular}

\begin{tabular}{|l|l|l|l|}
\hline & & $\begin{array}{l}\text { sekaligus } \\
\text { pembukaan }\end{array}$ & \\
\hline 5. & $10.00-$ & Penyampaian & Dr. \\
& 12.00 & $\begin{array}{l}\text { Materi } \\
\text { Penguatan }\end{array}$ & $\begin{array}{l}\text { Khayatun } \\
\text { Nufus, } \\
\end{array}$ \\
& & $\begin{array}{l}\text { Ekonomi } \\
\text { Keluarga }\end{array}$ & S.E.,M.Si \\
\hline 6. & $12.00-$ & ISOMA & \\
7 & 13.00 & Penutup & \\
& 13.00 & & \\
\hline
\end{tabular}

Hari Sabtu, 14 November 2020

Tabel 4.2 Rundown Pelatihan hari kedua

\subsection{Metode Kegiatan}

Pelakanaan Pengabdian Kepada Masyarakat ini adalah bentuk pembekalan yang menggunakan metode : ceramah, diskusi, serta tanya jawab antara pemakalah dengan peserta, Peserta pelatihan ini adalah masyarakat yang berdomisili di sekitar Masjid Qubatul Islam, yang berada di satu wilayah Rukun Warga, terdiri dari beberapa Rukun Tetangga. Total peserta sebanyak 47 orang..

Pelatihan ini dilakukan dengan melalui pembekalan pengetahuan pentingnya penguatan ekonomi keluarga di tengah pandemi covit, dengan memberikan penjelasan materi terkait oleh narasumber yantg berkompeten. Materi penyampaiannya adalah melalui tahapan :

1. Pemberian penjelasan akan pentingnya ketahanan ekonomi keluarga.

2. Memberi penjelasan berbagai cara yang dapat dilakukann oleh masyarakat dann keluarga untuk memperoleh pendapatan tambahan di tengah situasi ekonomi yang memburuk sebagai dampak pandemi covid 19.

3. Memberikan pelatihan salah satu alternatif yang dapat dilakukan keluarga dan masyarakat untuk peningkatan ekonominya dengan cara budidaya ikan lele dengan menggunakan media ember, sekaligus melakukan penanaman kangkung di atas budidaya lele tersebut. Hal ini memberikan solusi bagi masyarakat yang memiliki lahan terbatas 


\section{JURNAL ABDIMAS

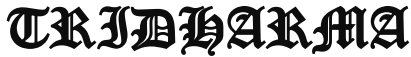

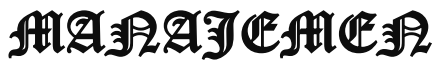

P-ISSN 2615-6849, E-ISSN 2716-070X

Jurnal ABDIMAS Vol.3,No.1,Desember 2021,Hal(57-71)

@ Prodi Manajemen Fakultas Ekonomi Universitas Pamulang

Email: abdimasjurnal.unpam@ gmail.com Telp: (021) 741-2566 untuk mampu mengefisienkan penggunaanya dengan aktifitas yang dapat menambah pendapatan atau menguatkan ekonominya.

4. Memberikan modal untuk tahap pertama bagi peserta berupa ember dan bibit ikan lele beserta pakannya, , serta menambah bibit kangkung untuk ditumpangkan pada ember tersebut pada tempat yang sudah tersedia.

5. Memberikan pendampingan kepada masyarakat peserta pelatihan yang sudah menerima bantuan dengan terus memantau perkembangan budidaya ikan lele di ember beseeta tanaman kangkungnya .

\section{HASIL DAN PEMBAHASAN Hasil Kegiatan \\ Hasil}

Pelaksanakan Pengabdian Kepada Masyarakat selama dua hari berturut turut, dalam bentuk memberikan pelatihan bagi masyarakat yang bertempat tinggal di sekitar Masjid Qubatul Islam , Kelurahan Bambu Apus Kecamatan Pamulang Tangerang Selatan. Antusius masyarakat untuk mengikuti Pelatihan sebagai wujud pengabdian TIM DOSEN untuk masyarakat sekitar kampus, menjadi semangat tersendiri bagi Tim. Pelatihan diikuti selain oleh pengurus Masjid Qubatul Islam, diikuti juga oleh 47 masyarakat yang tersebar di berbagai RT sekitar Masjid.

Pelatihan ini memberi peluang baru bagi masyarakat untuk mampu memahami dan menjadikan solusi dan peluang memenuhi kebutuhan primer hidupnya, yaitu kebutuhan makan, serta membuka peluang upaya menambah nilai ekonomi keluarga jika nantinya mampu mengembangkannya supaya dapat dijual ke pasar.

Pelatihan dalam pengabdian masyarakat ini juga memberi harapan baru bagi masyarakat setempat untuk meningkatkan ketahanan ekonomi mereka. Dengan kata lain, dengan diadakannya pengabdian kepada masyarakat melalui pelatihan budidaya ikan lele dan budidaya tanaman kangkung, memberikan manfaat yang sangat berarti bagi masyarakat sekitar Masjid Qubatul Qur'an kelurahan Bambu Apus Pamulang Tangerang Selatan.

\subsection{Pembahasan}

Solusi yang ditawarkan pada pelaksanaan pengabdian kepada masyarakat kali ini adalah solusi yang berbeda dari sebelumnya. Mungkin dulu pemerintah dengan berbagai program untuk membantu masyarakat lapisan menengah ke bawah salah satunya adalah melalui penyaluran program Unit Mikro, Kecil dan Menengah yang menyediakan produkproduk hasil karya masyarakat itu sendiri.

Perkembangan penduduk yang sangat pesat menyebabkan semakin banyaknya kebutuhan lahan yang diperutukkan bagi pembangunan rumah, dan hal ini menyebabkan semakin menyempitnya lahan kosong. Lahan kosong yang semakin berkurang tersebut mendorong pemikiran baru, dengan didorong teknologi dalam mengelola kemungkinan aktifitas yang bernilai ekonomis. Hal ini juga disebabkan faktor kebutuhan modal yang tidak sepenuhnya tidak mampu dimiliki oleh masyarakat.

Keterbatasan ekonomi dan sempitnya lahan yang dimiliki inilah alasan yang menyebabkan ketidak mampuan menyediakan modal, sehingga mendorong penggunaan budidaya dukdamber ini.

\section{KESIMPULAN DAN SARAN}

\section{Kesimpulan}

Kegiatan Pengabdian Kepada Masyarakat ini memberikan gambaran yang nyata dan jelas bahwa :

1. Masyarakat sebagian besar belum memahami pembudidayaanikan dan tanaman..

2. Masyarakat sangat terbantu dengan adanya pelatihan tentang dukdamber, yaitu pembudidayaan ikan lele dalam ember yang sangat praktis dan ekonomis namun diharapkan mampu memberikan keuntungan dari pengelolaanya.

3. Masyarakat yang sebelumnya belum pernah menanam kangkung di atas ember bersamaan dengan 


\section{JURNAL ABDIMAS

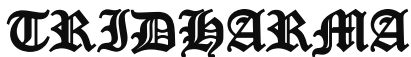

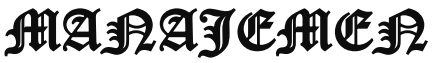

P-ISSN 2615-6849, E-ISSN 2716-070X

Jurnal ABDIMAS Vol.3,No.1,Desember 2021,Hal(57-71)

@Prodi Manajemen Fakultas Ekonomi Universitas Pamulang

Email: abdimasjurnal.unpam@ gmail.com Telp: (021) 741-2566 budidaya ikan lele, harus mampu menanam kangkung dalam wadah yang sama dengan ikan lele, sebagai bahan yang dapat dikonsumsi sendiri.

4. Masyarakat yang sebelumnya belum belum mencoba, setelah pelatihan harus mampu menanam kangkung dalam wadah yang sama dengan ikan lele, selain dikonsumsi sendiri, juga dapat memberi nilai tambah pendapatan dengan menjual hasil budidaya tersebut, sebagai upaya penguatan ketahanan ekonomi keluarga

\section{Saran}

1. Masyarakat hendaknya mengikuti pelatihan sejenis secara tertib dan disiplin.

2. Untuk ke depannya masyarakat dapat mempraktekan ilmu dan teori yang diajarkan selama pelatihan

3. Mengembangkan budidaya ikan lele dalam ember, akan bertambah satu ember menjadi bertambah dan terus bertambah, bukan sebaliknya .

4. Melaksanakan pendampingan sebagai tindak lanjut pelatihan yang sudah dilaksanakan sehingga akan terlihat tingkat penyerapan ilmu dari pelatihan tersebut.

5. Perlu secara intens dan berkelanjutan dalam melakukan pembinaan kepada masyarakat yang menjadi tempat yg dipilih dalam Pengabdian Kepada Masyarakat.

\section{DAFTAR PUSTAKA}

- Cascio, F. Wayne, 20013, Human Resource Management Productivity, Quality of

Work Life, Profits, Sixth Edition, McGraw-Hill Irwin, Boston

-Chadirin, Y. 2001. Pelatihan Aplikasi

Teknologi Hidroponik Untuk

Pengembangan Agribisnis Perkotaan.
Bogor: Lembaga Penelitian Institut Pertanian Bogor.

- Cut Zurnali, 2014, Pengaruh Pelatihan dan Motivasi Terhadap Perilaku Produktif

Karyawan pada Divisi Long Distance PT Telkom Indonesia, Tbk, Tesis,

Bandung

Program Pascasarjana Unpad,

- De Cenzo and Robbins, 2019, Human Resource Management, Sixth Edition, New

Inc.

York, John Wiley \& Sons,

- Dessler, Gary, 2017, Human Resource Management, Seventh Edition, Prentice Hall,

Inc.,New Jersey

-- Diver, S. 2006. Aquaponics - integration of hydroponics with aquaculture. ATTRA

National
$\begin{gathered}\text { Agriculture Information } \\ \text { Diakses dari https:// } \\ \text { attra.ncat.org/. Asao, }\end{gathered}$

- Fajar Sidik S.H., M.Medkom. 2020, Kepala Seksi Pembinaan Pelaksanaan Anggaran IA. Kanwil Ditjen Perbendaharaan Provinsi Aceh.

- Habiburrohman, H. 2018. Aplikasi Teknologi Akuaponik Sederhana Pada Budidaya

Ikan Air Tawar Untuk Optimalisasi Pertumbuhan Tanaman Sawi

(Brassica Juncea L.). [Skripsi]. UIN Raden Intan Lampung. 94 Hal.

- Jones, J. Benton. 2005. A Practical Guide for Soilless Grower. Boston: CRC Press.

Rakocy JE,

- Masser MP dan Losordo TM. 2006. Recirculating aquaculture tank production 


\section{JURNAL ABDIMAS

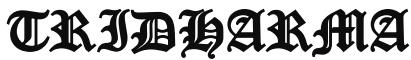

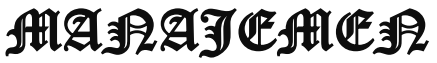

P-ISSN 2615-6849, E-ISSN 2716-070X

Jurnal ABDIMAS Vol.3,No.1,Desember 2021,Hal(57-71)

@ Prodi Manajemen Fakultas Ekonomi Universitas Pamulang

Email: abdimasjurnal.unpam@ gmail.com Telp: (021) 741-2566 systems: Aquaponics integrating fi sh and plant culture. November

No.454. Diakses dari http://www.aces.edu/dept/fisheries/aq uaculture/documents/309884SRAC454.pdf.

- Noe, Hollenbeck, Gerhart, Wright, 2003, Human Resource Management,

International Edition, The McGraw-hill Companies, Inc. New York

- Toshiki. 2012. Hydroponis-A Standard Methodology for Plant Biological Researches.

\section{Croatia: Intech.}

- Elektronik Laporan Hasil Pelatihan, pemda Propinsi Jawa Tengah

- https://www.99.co/blog/indonesia/tekni k-budikdamber-lele/

- tips-trik-mengembangkan-hidroponikdan-budikdamber-untuk-pemula

Pasaribu, V. L. D., Jannah, M., Fazar, M., Putra, S. P., Monalisa, M., \& Sofa, M. (2021). MENINGKATKAN PRODUKTIVITAS USAHA DIMASA PANDEMI PADA IBU PKK RT 004/003 KELURAHAN SAWAH BARU CIPUTAT, TANGERANG SELATAN. Abdi Laksana: Jurnal Pengabdian Kepada Masyarakat,2(2), 295301.

Pasaribu, V. L. D., Septiani, F., Rahayu, S., Lismiatun, L., Arief, M., Juanda, A., ... \& Rahim, R. (2021). Forecast Analysis of Gross Regional Domestic Product based on the Linear Regression Algorithm Technique.

Priadi, A., Pasaribu, V. L. D., Virby, S., Sairin, S., \& Wardani, W. G. (2020). Penguatan Ekonomi Kreatif Berbasis Sumber Daya Desa Dikelurahan Rempoa. Abdi
Laksana: Jurnal Pengabdian Kepada Masyarakat, 1(3), 356-35

Pasaribu, V. L. D., Priadi, A., Anismadiyah, V., Rahayu, S., \& Maduningtias, L. (2021). PENYULUHAN KREATIF DAN INOVATIF MENINGKATKAN MUTU PRODUKSI UMKM DI DESA BELEGA KABUPATEN GIANYAR. Pro Bono Jurnal Pengabdian Kepada Masyarakat, 1(02).

Pasaribu, V. L. D. (2021). PELATIHAN BERBASIS ONLINE DI ERA COVID-19. Jurnal Abdimas Tri Dharma Manajemen, 2(3), 26-32.

- https://klikkalsel.com/mengenalbudikdamber-budidaya-ikan-sekaligusberkebun

- https://makassar.terkini.id/budikdampe r-inilah-salah-satu-solusi-panganmasa-depan/

- https://www.haibunda.com/momslife/20200519141953-76-141003/tipsmenanam-kangkung-dan-ikan-leledalam-ember-cocok-di-lahan-terbatas

- https://www.kompasiana.com/alcirebo ni/5d01f80c3d68d523286e1ab3/budida ya-ikan-lele-dan-kangkung-dalamember-kangkung-tidak-bau-dan-tidakperlu-di-kuras

- https://bpsdmd.jatengprov.go.id/eprope r/inovasi.php?id=973\#: :text=Program \%20Pemberdayaan\%20Ekonomi\%20K eluarga\%20bertujuan,dalam\%20bidang \%20usaha\%20ekonomi\%20produktif. \&text=Melalui\%20kelompok\%20yang \%20akan\%20terbentuk,akses\%20yang \%20ada\%20dan\%20tersedia.

- https://www.kemenkopmk.go.id/pemer intah-bahas-kebijakan-penguatanekonomi-keluarga

- https://mediaindonesia.com/ekonomi/3 55171/pemerintah-bahas-kebijakanpenguatan-ekonomi-keluarga 


\section{JURNAL ABDIMAS

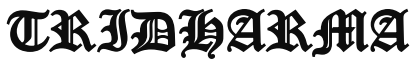

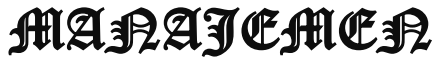

- https://www.medcom.id/nasional/perist iwa/ob33opYb-pemerintah-kajikebijakan-penguatan-ekonomikeluarga

\section{FOTO KEGIATAN}
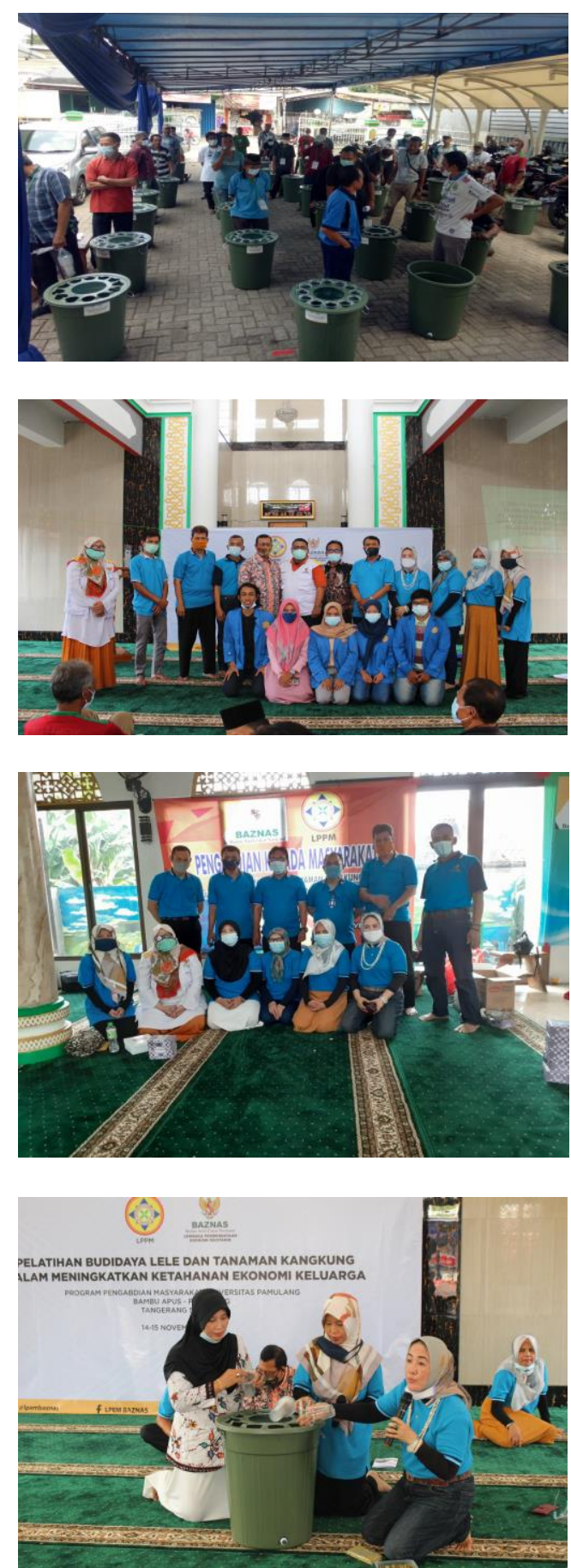